\title{
Quality Evaluation of Dried Fermented Locust Bean and Soybean Condiments
}

\author{
Evelyn Mnguchivir Tersoo-Abiem, Stephen Sule, Izuchukwu Iwuamadi, and Esther Obiye Awulu
}

\section{ABSTRACT}

The study was carried out in order to establish the suitability of fermented soybean condiment as an alternative to fermented locust bean condiment in meal preparations. The dried fermented condiments were subjected to chemical, microbial and sensory evaluation using standard methods. Results revealed significantly $(\mathrm{p}<0.05)$ higher protein $(54.06 \%)$, ash $(6.21 \%)$, crude fat $(14.15 \%)$ and $\mathrm{pH}(\mathbf{8 . 9 0})$ content in fermented soybean condiment. Higher values of $44.72 \mathrm{mg} / 100 \mathrm{~g}, 20.06 \mathrm{mg} / 100 \mathrm{~g}, 612.40 \mathrm{mg} / 100 \mathrm{~g}$ and $164.34 \mathrm{mg} /$ $100 \mathrm{~g}$ were also observed in fermented soybean condiment with respect to iron, magnesium, potassium, and calcium respectively. Furthermore, fermented soybean condiment revealed significantly $(p<0.05)$ higher vitamin content of $647.62 \mathrm{UI} / 100 \mathrm{~g}, 0.047 \mathrm{mg} / 100 \mathrm{~g}$ and $0.030 \mathrm{mg} / 100 \mathrm{~g}$ for provitamin $A$ ( $\beta$-Carotene), vitamins $B_{1}$ and $B_{2}$ respectively. Microbiologically, total plate count of $1.7 \times 10^{5} \mathrm{CFU} / \mathrm{g}$ and $1.4 \times 10^{5} \mathrm{CFU} / \mathrm{g}$ were observed for fermented soybean and locust bean condiments respectively. There was however no fungal growth observed in both condiments. Isolation and characterization of bacteria isolates revealed Bacillus subtilis as the common microorganism in both condiments. Bacillus licheniformis was predominant in locust bean condiment, while Bacillus pumilus was more in soybean condiment. With the exception of appearance, there was no significant difference $(p>0.05)$ between the condiments in terms of their sensory attributes. Sensory scores for fermented soybean condiment were however higher than that of fermented African locust bean. From this study, soybean condiment may be a suitable substitute to locust bean (Parkia biglobosa) condiment, following the gradual extinction of the plant.

Keywords: African locust bean, Bacillus species, Dried fermented condiments, Soybean.

\section{INTRODUCTION}

Fermentation is the process of chemically transforming organic substrates into simpler compounds by the action of enzymes which are produced by microorganisms such as moulds, yeasts, and bacteria [1]. Many crops including legumes and oil seeds are subjected to fermentation to improve their physical characteristics, reduce toxicity, improve palatability, improve flavour, increase nutrient content and bioavailability and also to impart some microbial properties [2].

Condiments are substances applied to food in the form of a sauce, powder, spread or anything similar, to enhance or improve flavour [3], [4]. They are also perceived as low-cost meat substitute added to soups by low-income families in parts of Nigeria [4], [5]. Oil seeds such as African locust bean, melon seed, castor oil seed, mesquite bean and soybean are usually fermented to make condiments [6].

African locust bean (Parkia biglobosa) seeds are rich in protein. The tree is widely distributed in Northern Nigeria, although can be found in many other parts. The bean is consumed mainly because of its richness in minerals and proteins [1]. In Nigeria, the seeds are usually fermented to a tasty food condiment called iru by the Yoruba tribe and nune by the Tiv tribe. This fermented African locust bean meal

\author{
Submitted : March 06, 2021 \\ Published : April 30, 2021 \\ ISSN: $2684-1827$ \\ DOI: 10.24018 /ejfood.2021.3.2.261 \\ E. M. Tersoo-Abiem* \\ Department of Food Science and \\ Technology, University of Agriculture, \\ Makurdi, Benue State, Nigeria. \\ (e-mail: emtabiem@gmail.com) \\ S. Sule \\ Department of Food Science and \\ Technology, University of Agriculture, \\ Makurdi, Benue State, Nigeria. \\ (e-mail: stevesule ${ }^{@}$ gmail.com) \\ I. Iwuamadi \\ Department of Food Science and \\ Technology, University of Agriculture, \\ Makurdi, Benue State, Nigeria. \\ (e-mail: izunnaiwu@ gmail.com) \\ E. O. Awulu \\ Department of Food Science and \\ Technology, University of Agriculture, \\ Makurdi, Benue State, Nigeria. \\ (e-mail: estherobiye1 $@$ gmail.com)
}

*Corresponding Author remains one of the most important condiments of natural origin in West Africa and central savannah region [7]. It is used as a flavour intensifier for soups and stews and is preferable in many traditional dishes.

Soybean (Glycine max) is an important oil seed like African Locust bean, also belonging to the family of leguminosae and is usually grown as a food crop. Soybean finds various applications ranging from production of soy oil, soymilk, infant formula, instant breakfast foods, confectionary, and bakery products, and also in the production of traditional seasoning or condiments (daddawa or dawadawa) [8].

Due to deforestation activities, African locust bean trees are at risk of extinction and gradually becoming unavailable for use as condiments. For that reason, it is essential to study the quality characteristics of fermented soybean condiment to ascertain its suitability as a useful alternative.

\section{OBJECTIVE}

The objective of this paper is to evaluate the quality characteristics of dried fermented locust bean and dried fermented soybean condiments. 


\section{METHODOLOGY}

\section{A. Source of Materials}

Fermented locust bean and soybean condiments were obtained from Wurukum market, Makurdi, Benue State. The samples were dried, milled, packed in transparent bags and placed in air tight containers for further analyses.

\section{B. Chemical Analysis}

Proximate Composition (moisture, crude protein, crude fat, ash, crude fibre and carbohydrate contents) of the dried fermented locust and soybean condiments were determined according to the methods described by AOAC [9]. Minerals (Iron, Calcium, Magnesium, and Potassium contents) were analysed using atomic absorption spectrophotometer as described by AOAC [9]. Pro-vitamin A, vitamins $\mathrm{B}_{1}$, and $\mathrm{B}_{2}$ were determined using high performance liquid chromatography (Model: BLC-10/11, Buck Scientific, USA) following methods described by AOAC [9]. The $\mathrm{pH}$ of the samples was determined using a pye unicam $\mathrm{pH}$ meter (Model 290 MK2). Two (2) gram of each dried fermented condiments were mixed separately in $20 \mathrm{ml}$ of distilled water and the suspension used for $\mathrm{pH}$ determination.

\section{Microbial Analysis}

Bacteria and fungi were enumerated from the samples using nutrient agar and potato dextrose agar respectively by the pour plate technique. Stock cultures from the samples were prepared on nutrient agar slants and kept in the refrigerator for further use. The bacterial isolates were identified by standard microbiological measures [10]. The characterization of bacteria isolates was based on Gram reaction, morphological and cultural characteristics and relevant biochemical tests as documented in the Bergey's Manual of Determinative Microbiology [11].

\section{Sensory Evaluation}

The condiments were served to a 15 -member semi-trained panel that were familiar with the products so as to evaluate such attributes as appearance, aroma, texture and overall acceptability based on a 9-point hedonic scale [12].

\section{E. Statistical Analysis}

Experiments were done in triplicates. Means and standard deviations were calculated and data subjected to two sample T-test in order to separate their means, using Genstat (17th edition).

\section{RESULTS AND DISCUSSION}

\section{A. Chemical Composition of Fermented Locust Bean and Soybean Condiments}

Result for chemical composition of fermented locust bean and soybean condiments is presented in Table I. The protein $(54.06 \%)$, ash $(6.21 \%)$ and crude fat $(14.15 \%)$ content of fermented soybean condiment were higher than those in fermented locust bean condiment $(47.24 \%, 5.61 \%$ and $13.55 \%$ respectively). On the other hand, moisture $(9.46 \%)$, crude fibre $(3.52 \%)$ and carbohydrate $(20.62 \%)$ contents were higher in condiment from locust bean than that from soybean.

The values for protein reported in the present study were slightly higher than values documented for freshly fermented locust bean and soybean condiment by other researchers [2], [13]. Proteolysis (breakdown of protein into simpler polypeptides or amino acids) has been reported as the main metabolic activity during the fermentation of African locust bean and soybean condiments [3], [13]. Increase in protein with fermentation has been reported by Oboh [4]. The author asserted that the apparent increase in protein could be due to microbial proliferation of microorganisms in form of single cell protein. Anigo et al. [14] also reported that microorganisms which were involved in the fermentation process but may have died could contribute to the high crude protein content.

Higher ash content has been linked with higher micronutrient composition of foods [15]. The high ash contents of the fermented condiments as depicted in the present study suggest that they can be incorporated in several food systems to improve micronutrient composition, thereby reducing hidden hunger especially in vulnerable regions of the world. The values obtained in this study were higher than those obtained by other researchers [13], [16], [17]. Makanjuola and Ajayi [1] observed that operations such as boiling, soaking in water and dehulling of the bean seeds prior to fermentation, decreases the ash content of condiments.

The increase in fat content of the fermented condiments may be attributed to the activities of lipolytic enzymes, which hydrolyze fat to glycerol and fatty acid. This result agrees with the observations of [2]. Other researchers [4], [17] observed higher values for fermented locust bean and soybean condiments. Dietary fats have been shown to enhance the taste and acceptability of foods, slow gastric emptying and intestinal motility, thereby prolonging satiety and facilitate the absorption of lipid-soluble vitamins [18].

The low moisture content observed is an indication of the efficiency of drying as well as good keeping quality of the food materials [19]. The result obtained in this study were higher than those reported obtained by [2].

The ability of crude fibre to lower serum triglyceride, serum total cholesterol, and liver cholesterol has been reported [20]. Crude fibre content of the condiments obtained in the present study were lower than values $(6.49 \%$ for fermented locust bean and and $4.54 \%$ soybean condiments respectively) reported by Omodara and Olowomofe [2]. According to Omafuvbe et al. [21], boiling and dehulling of African locust bean seed reduces its crude fibre by $61 \%$.

The low carbohydrate content of the fermented condiments may be due to the action of the fermenting organisms to utilize it as their major carbon source [22]. Values were however higher than those reported for other protein-based condiments [4].

High $\mathrm{pH}$ values of 8.70 and 8.90 were observed for locust bean and soybean condiments respectively. Similar alkaline $\mathrm{pH}$ values were observed by Makanjuola and Ajayi [1]. The authors observed that the alkalinity could be attributed to rapid proteolytic activities and release of ammonia by microorganisms involved in fermentation. They also informed that the discharged ammonia was responsible for the pungent smell peculiar with most vegetable protein fermented products. 
TABLE I: CHEMICAL COMPOSITION OF FERMENTED LOCUST BEAN AND SOYBEAN CONDIMENTS

\begin{tabular}{cccccccc}
\hline Sample & $\begin{array}{c}\text { Moisture } \\
(\%)\end{array}$ & $\begin{array}{c}\text { Crude } \\
\text { protein }(\%)\end{array}$ & Ash $(\%)$ & $\begin{array}{c}\text { Crude fat } \\
(\%)\end{array}$ & $\begin{array}{c}\text { Crude } \\
\text { fibre }(\%)\end{array}$ & $\begin{array}{c}\text { Carbohydrate } \\
(\%)\end{array}$ & $\mathrm{pH}$ \\
\hline A & $9.46 \pm 0.01$ & $47.24 \pm 0.03$ & $5.61 \pm 0.01$ & $13.55 \pm 0.01$ & $3.52 \pm 0.01$ & $20.62 \pm 0.01$ & $8.70 \pm 0.00$ \\
B & $8.88 \pm 0.01$ & $49.06 \pm 0.01$ & $6.21 \pm 0.02$ & $14.15 \pm 0.02$ & $3.18 \pm 0.01$ & $18.52 \pm 0.01$ & $8.90 \pm 0.00$ \\
P-value & $<0.0001$ & $<0.0001$ & 0.0001 & 0.0001 & 0.0001 & $<0.0001$ & 0.0001 \\
\hline
\end{tabular}

Values are means \pm standard deviation of triplicate determinations. Means in same column with p-value less than 0.05 are significantly different ( $<<0.05$ ) Sample A = Dried Fermented Locust bean Condiment, Sample B = Dried Fermented Soybean Condiment.

\section{B. Mineral Composition of Fermented Locust Bean and Soybean Condiments}

Table II shows results for mineral composition fermented locust bean and soybean condiments. The high level of minerals observed in the condiments is directly linked with their relatively high ash contents. High mineral content of fermented locust bean and other legume-based condiments has been reported [6]. Values for iron (44.72 mg/100 g), magnesium (20.06 mg/100 g), potassium $(612.40 \mathrm{mg} / 100 \mathrm{~g})$ and calcium $(164.34 \mathrm{mg} / 100 \mathrm{~g})$ were higher in soybean condiment, indicating that it is a richer source of micronutrients than African locust bean. Oboh [4] however reported lower values for protein-based condiments. Varietal differences and environmental conditions may have accounted for the variation in results with those from other researchers. The functions of minerals, including their deficiencies are well documented in literature [23], [24].

TABLE II: SELECTED MineRAL COMPOSITION (MG/100 G) OF DRIED FERMENTED LOCUST BEAN AND SOYBEAN CONDIMENTS

\begin{tabular}{ccccc}
\hline Sample & Iron & Magnesium & Potassium & Calcium \\
\hline A & $41.53 \pm 0.00$ & $18.68 \pm 0.01$ & $425.67 \pm 0.04$ & $142.69 \pm 0.01$ \\
B & $44.72 \pm 0.01$ & $20.06 \pm 0.01$ & $612.40 \pm 0.05$ & $164.34 \pm 0.01$ \\
P-value & 0.027 & 0.0200 & $<0.0001$ & 0.0017 \\
\hline
\end{tabular}

Values are means \pm standard deviation of triplicate determinations. Means in same column with $\mathrm{p}$-value less than 0.05 are significantly different $(\mathrm{p}<0.05)$ Sample A = Dried Fermented Locust bean Condiment Sample B = Dried Fermented Soybean Condiment.

\section{Vitamin Content of Fermented Locust Bean and Soybean Condiments}

Values for beta-carotene $(647.62 \mathrm{IU} / 100 \mathrm{~g})$, vitamin $\mathrm{B}_{1}$ $(0.047 \mathrm{mg} / 100 \mathrm{~g})$ and vitamin $\mathrm{B}_{2}(0.030 \mathrm{mg} / 100 \mathrm{~g})$ were higher in the fermented soybean condiment than in African locust bean (Table III). Adegoroye [25] reported vitamin $\mathrm{B}_{1}$ levels of $0.78 \mathrm{mg} / 100 \mathrm{~g}$ and $0.05 \mathrm{mg} / 100 \mathrm{~g}$ in soybean and African locust bean condiments respectively. The author also reported vitamin $B_{2}$ value of $0.28 \mathrm{mg} / 100 \mathrm{~g}$ and $0.72 \mathrm{mg} /$ $100 \mathrm{~g}$ in soybean and African locust bean condiments respectively. Low beta-carotene, vitamin $B_{1}$ and $B_{2}$ levels in the present study may be due to leaching of soluble content into the cook water prior to fermentation, as well as due to sun drying [26]. Vitamin A (retinol) in the form of betacarotene is essential for growth and development, normal functioning of the visual system, maintenance of epithelial cellular integrity, immune function, and reproduction [26]. Vitamin $B_{1}$ (thiamin) is useful in the generation of energy from carbohydrates and for nervous system functions, while vitamin $\mathrm{B}_{2}$ is important in red blood cell formation and also in growth and development [27].
TABLE III: SELECTED VITAMIN CONTENT OF DRIED FERMENTED LOCUST BEAN AND SOYBEAN CONDIMENTS

\begin{tabular}{cccc}
\hline Samples & $\begin{array}{c}\text { Beta-Carotene } \\
(\mathrm{IU} / 100 \mathrm{~g})\end{array}$ & $\mathrm{B}_{1}(\mathrm{mg} / 100 \mathrm{~g})$ & $\mathrm{B}_{2}(\mathrm{mg} / 100 \mathrm{~g})$ \\
\hline $\mathrm{A}$ & $523.53 \pm 0.03$ & $0.043 \pm 0.00$ & $0.026 \pm 0.00$ \\
$\mathrm{~B}$ & $647.62 \pm 0.01$ & $0.047 \pm 0.00$ & $0.030 \pm 0.00$ \\
P-value & $<0.0001$ & $<0.0001$ & 0.0742 \\
\hline
\end{tabular}

Values are means \pm standard deviation of triplicate determinations. Means in same column with $\mathrm{p}$-value less than 0.05 are significantly different $(\mathrm{p}<0.05)$. Sample A = Dried Fermented Locust bean Condiment.

Sample B = Dried Fermented Soybean Condiment.

\section{Microbial quality of Fermented Locust Bean and Soybean Condiments}

Total plate count of $1.4 \times 10^{5} \mathrm{CFU} / \mathrm{g}$ and $1.7 \times 10^{5} \mathrm{CFU} / \mathrm{g}$ was observed for locust bean and soybean condiments respectively (Table IV). There were no traces of fungal infestation in the condiments, indicating of good hygienic handling [28]. This is also supported by the work of UaboiEgbenni et al. [29] who reported that microbial fermentation of dawadawa has been found to involve only bacteria since fungi present has been regarded as incidental and does not play any notable role in its fermentation.

From the cultural and biochemical characterization of isolates, Bacillus subtillis and Bacillus licheniformis were the predominant microorganisms in locust bean condiment after fermentation and drying, while Bacillus subtilis and Bacillus pumilus were mostly found in soybean condiment (Table V). This is confirmed by the work of other researchers [28], [30], [31]. The presence of Bacillus subtilis in these condiments makes it a potential probiotic vehicle, with the potential of offering both nutritive and functional benefits.

TABLE IV: MicRoBiologiCAL LOAD OF DRIED FERMENTED LOCUST

\begin{tabular}{ccc} 
& \multicolumn{3}{c}{ BeAN AND SOYBEAN CONDIMENTS } \\
\hline \multirow{2}{*}{ Sample } & $\begin{array}{c}\text { Total Plate Count } \\
(\mathrm{CFU} / \mathrm{g})\end{array}$ & $\begin{array}{c}\text { Yeast and Mould } \\
\text { Count }(\mathrm{CFU} / \mathrm{g})\end{array}$ \\
\hline $\mathrm{A}$ & $1.4 \times 10^{5}$ & $\mathrm{Nil}$ \\
$\mathrm{B}$ & $1.7 \times 10^{5}$ & $\mathrm{Nil}$ \\
\hline
\end{tabular}

Sample A $=$ Dried Fermented Locust bean Condiment.

Sample B $=$ Dried Fermented Soybean Condiment.

\section{E. Sensory properties of Fermented Locust Bean and Soybean Condiments}

Table VI shows the sensory scores of fermented African locust bean and soybean condiments. Soybean condiment was preferred over African locust bean in all sensory attributes evaluated. With the exception of appearance, there was no significant difference $(\mathrm{p}<0.05)$ in sensory attributes of the condiments. The scores for texture and aroma of the condiments are similar to that reported by Omafuvbe et al. [32]. 
TABLE V: CULTURAL AND BIOCHEMICAL CHARACTERISTICS OF BACTERIA ISOLATES FROM DRIED FERMENTED LOCUST BEAN AND SOYBEAN CONDIMENTS

\begin{tabular}{|c|c|c|c|c|}
\hline & \multicolumn{4}{|c|}{ Isolates } \\
\hline Tests & A1 & $\mathrm{A} 2$ & B1 & B2 \\
\hline Colony Morphology & $\begin{array}{c}\text { White, large, opaque, slightly } \\
\text { convex, entire edge }\end{array}$ & $\begin{array}{l}\text { Cream, large, opaque, } \\
\text { flat, undulate edge }\end{array}$ & $\begin{array}{c}\text { Gray, medium sized, } \\
\text { opaque, flat, entire edge }\end{array}$ & $\begin{array}{c}\text { Cream, large, opaque, } \\
\text { Slightly convex, entire edge }\end{array}$ \\
\hline Gram reaction & + short rod & + long rod & $+\operatorname{rod}$ & + short rod \\
\hline Catalase & + & + & + & + \\
\hline Anaerobic growth & - & + & - & - \\
\hline Starch hydrolysis & + & + & - & + \\
\hline Indole & - & _ & + & - \\
\hline Citrate & - & + & - & - \\
\hline Lipolytic activity & + & + & + & + \\
\hline Lecithinase & - & - & - & - \\
\hline Nitrate reduction & + & + & + & + \\
\hline Motility & + & + & + & + \\
\hline Glucose & + & + & + & + \\
\hline Sucrose & - & - & + & - \\
\hline Mannitol & + & + & + & + \\
\hline Fructose & + & + & - & + \\
\hline Casein hydrolysis & + & + & + & + \\
\hline & Bacillus subtilis & Bacillus licheniformis & Bacillus pumilus & Bacillus subtilis \\
\hline
\end{tabular}

A1, A2 = Dried fermented locust bean condiment.

$\mathrm{B} 1, \mathrm{~B} 2=$ Dried fermented Soybean condiment.

TABLE VI: SENSORY SCORES OF DRIED FERMENTED LOCUST BEAN AND SOYBEAN CONDIMENTS

\begin{tabular}{ccccc}
\hline Sample & Appearance & Texture & Aroma & $\begin{array}{c}\text { General } \\
\text { acceptability }\end{array}$ \\
\hline A & $6.73 \pm 0.36$ & $6.40 \pm 0.32$ & $6.20 \pm 0.52$ & $7.20 \pm 0.33$ \\
B & $7.87 \pm 0.21$ & $7.27 \pm 0.38$ & $6.73 \pm 0.44$ & $7.53 \pm 0.32$ \\
P-value & 0.0006 & 0.0004 & 0.0008 & 0.0399 \\
\hline
\end{tabular}

Values are means $(\mathrm{n}=15) \pm$ standard deviation. Means in same column with p-value less than 0.05 are significantly different $(\mathrm{p}<0.05)$

Sample A = Dried Fermented Locust bean Condiment.

Sample B = Dried Fermented Soybean Condiment.

\section{CONCLUSION}

The study evidences the potential of dried fermented soybean condiment as a valuable substitute for African locust bean condiment owing to its comparable nutritional, microbiological and sensory attributes. Regular consumption of these nutrient-rich condiments will not only confer positive nutritional benefits, but improvement in flavour of many traditional diets.

\section{REFERENCES}

[1] Makanjuola, O. M. and Ajayi, A. (2012). Effect of Natural Fermentation on the Nutritive Value and Mineral Composition of African Locust Beans. Pakistan Journal of Nutrition, 11(1):11-13.

[2] Omodara, T. R. and Olowomofe, T. O. (2015). Effects of Fermentation on the Nutritional Quality of African Locust Bean and Soybean. International Journal of Science and Research, 4(1):1069-1071.

[3] Ajayi, O. A. (2014). Bacteriology and Qualitative Study of African Locust Bean (Parkia biglobosa). Open Journal of Social Sciences, 2:73-78.

[4] Oboh, G. (2006). Nutrient and Antinutrient Composition of Condiments Produced from some Fermented Underutilized Legumes. Journal of Food Biochemistry, 30:579-588.

[5] Olajuyigbe, F. M. and Ajele, J. O. (2008). Some properties of extracellular protease from Bacillus licheniformis LBBL-11 isolated from "iru", a traditionally fermented African locust bean condiment. African Journal of Biochemistry Research, 2(10):206-210.

[6] Ayo-Lawal, R. A., Osoniyi, R. O., Rivera, G. and Elufisan, T. O. (2016). Fermented Condiments from Melon (Citullus vulgaris) and African Locust Bean (Parkia biglobosa) seeds-A review. Nigerian Food Journal, 34(2):94-104.

[7] Daramola, B. (2015). Preliminary Studies on Antioxidative Potentials of Extracts of Defatted Locust Bean Condiment. Journal of Food Biosciences and Technology, 5(1):23-30.

[8] Iwe, M. O. (2003). The Science and Technology of Soybean. Rojoint Communication Services Ltd Enugu. pp 1-45.
[9] AOAC. (2012). Official Methods of Analysis, 19th Ed., Association of Official Analytical Chemists, Washington, DC.

[10] Harrigan, W. F. and McCance, M. E. (1976). Laboratory Methods in Food and Dairy Microbiology. Academic Press. London.

[11] Holt, J.G. (1977). The Shorter Bergey's Manual of Determinative Bacteriology, 8th ed., The Williams and Wilkins Co., Baltimore, Md

[12] Iwe, M. O. (2010). Handbook of Sensory Methods and Analysis. Rojoint Communication Services Ltd Enugu. pp 43-87.

[13] Nzelu, I. C. and Ubaka, K. K. (2019). Chemical, Amino Acid Profile and Sensory Quality of "Ogiri Soya" Produced from Soya Bean (Glycine Max). Cient PeriodiQue Nutrition, 3(5):1-9.

[14] Anigo, K. M., Ameh, D. A., Ibrahim, S. and Danbauchi, S S. (2010). Nutrient composition of complementary food gruels from malted cereals, soybeans and groundnut for use in North-Western Nigeria. African Journal of Food Science, 4(3): 65-72.

[15] Sule, S., Oneh, A. J. and Agba, I. M. (2019). Effect of carrot powder incorporation on the quality of pasta. MOJ Food Processing and Technology, 7(3):99-103.

[16] Ladokun, O. A. and Adejuwon, A.O. (2013). Nutritive and microbial analysis of two types of fermented locust bean (Parkia biglobosa). Academia Arena. 5(5): 15-17.

[17] Ndukwe, M. N. and Solomon, M. D. (2017). Proximate and Antinutrient Composition of Some Local Food Condiments in their Raw and Fermented Forms. International Journal of Biochemistry Research and Review, 20(1):1-8.

[18] FAO (2010). Fats and fatty acids in human nutrition - Report of an expert consultation. FAO Food and Nutrition Paper 91. Rome: Food and Agriculture Organization of the United Nations. pp. 55.

[19] Sengev, I. A., Nwobi, I. and Sule, S. (2016). Effect of Crayfish Inclusion on the Chemical and Sensory Properties of Ogi Prepared from Maize, Millet and Sorghum. International Journal of Nutrition and Food Sciences, 5(6):378-383.

[20] Hsu, P. K., Chien, P. J., Chen, C. H. and Chau, C. F. (2006). Carrot insoluble fibre-rich fraction lowers lipid and cholesterol absorption in hamsters. LWT Food Science and Technology, 39:337-342.

[21] Omafuvbe, B. O., Falade, O. S., Osuntogun, B. A., Adewusi, S. R. A. (2004). Chemical and Biochemical Changes in African Locust Bean (Parkia biglobosa) and Melon (Citrullus vulgaris) Seeds during Fermentation to Condiments. Pakistan Journal of Nutrition, 3(3):140145.

[22] Amao, J. A., Abel, O. O. and Agboola, J. O. (2013). Proximate Analysis and Sensory Evaluation of Iru Produced by Staphylococcus Sp. and Bacillus Sp. Separately. Journal of Environmental Science, Toxicology and Food Technology, 6(2): 26-30.

[23] Mlitan, A. M., Sasi, M. S. and Alkherraz, A. M. (2014). Proximate and Minor Mineral Content in some Selected Basil Leaves of Ocimum gratissimum L in Libya. International Journal of Chemical Engineering and Applications, 5:8-17.

[24] Ullah, R. J. A., Khader, I., Hussain, N. M., Talha, A. M. and Khan, N. (2012). Investigation of Macro and Micronutrients in Selected Medicinal Plants. African Journal of Pharmacy and Pharmacology, 69:1829-1832.

[25] Adegoroye, M. E. (1977). Effects of Fermentation on the Thiamin, Riboflavin, and Amino Acid Content of African Locust-Bean (Parkia 
filicoidea Welw) Seeds. Degree of Master of Science in Foods and Nutrition Thesis. pp. 1-38.

[26] WHO/FAO (2004). World Health Organization and Food and Agriculture Organization of the United Nations. Vitamin and mineral requirements in human nutrition. Second edition.

[27] Fattal-Valevski, A. (2011). "Thiamin (vitamin B1)". Journal of Evidence-Based Complementary and Alternative Medicine, 16 (1): 1220.

[28] Farinde, E. O., Adeniran, H. A. and Abiose, S. H. (2014). Comparative Microbial Assessment of Fermented Lima Bean (Phaseolus lunatus) and Locust Bean (Parkia biglobosa) in Production of Daddawa. British Microbiology Research Journal, 4(7):772-784.

[29] Uaboi-Egbenni, P. O., Okolie, P. N., Sobande, A. O., Alao, O., Teniola, O. and Bessong P. O. (2009). Identification of subdominant lactic acid bacteria in dawadawa (a soup condiment) and their evolution during laboratory-scale fermentation of Parkia biglobosa (African locust beans). African Journal of Biotechnology, 8(25):7241-7248.

[30] Ogunlade, J. T., David, O. M. and Ogundeji, T. K. (2019). Isolation of Bacillus subtilis from Fermented Locust Beans (iru) and its Probiotic effects on Growth Performance, Blood Profile and Carcass yield of Broiler chicken. International Journal of Life Sciences, 8(2):41-48.

[31] Babalola, R. O. and Giwa, O. E. (2012). Effect of Fermentation on Nutritional and Anti-nutritional properties of Fermenting Soybeans and the Antagonistic Effect of the Fermenting Organisms on Selected Pathogens. International Research Journal of Microbiology, 3(10):333-338.

[32] Omafuvbe, B. O., Abiose, S. H., Shonukan, O. O. (2002). Fermentationof soybean (Glycine max) for soy-daddawa production by starter cultures of Bacillus. Food Microbiology, 19:561-566. 